\title{
Design Philosophy and Poetic Thinking: Peter Sloterdijk's Metaphorical Explorations of the Interior
}

\author{
Thomas Lee \\ Design, Architecture and Building, University of Technology Sydney, \\ Australia
}

Rachael Wakefield-Rann

Institute for Sustainable Futures, University of Technology Sydney, Australia

\section{Abstract}

This article makes the argument that Peter Sloterdijk's philosophy provides a useful and thought-provoking basis for studies of contemporary indoor ecologies. Sloterdijk's philosophy is distinctively attentive to the various environments in which humans exist and of the ecological situation of beings in general. The notions of interiority explored in Sloterdijk's work, particularly the third volume of his Spheres trilogy Foams (2016), provide important tools for conceptualizing the changing nature of indoor spaces and contemporary modes of being in the world. Sloterdijk's approach to philosophical analysis exhibits a number of interrelated advantages that mesh well with the ambitions of human ecology, particularly in relation to indoor ecological conditions. These include his sustained conceptual exploration of technological and scientific developments, his distinctive use of rhetoric and philosophy in the characterization of human agency, and the close attention he pays to the relationship between being and design. This article unpacks the value of these perspectives through a sustained attention to Spheres III: Foams and aims to demonstrate why Sloterdijk's work provides an invaluable philosophical tool kit to foreground and unite scholarship in diverse fields exploring the relationship between interior spaces, human perception, and society.

Keywords: design philosophy, design theory, interior design, Peter Sloterdijk, philosophy of technology

1 Corresponding author: thomas.lee@uts.edu.au. 


\section{Introduction}

Peter Sloterdijk is currently Professor of Philosophy and Aesthetics at Karlsruhe University of Arts and Design in Germany. Founded in 1992 by celebrated architecture scholar Heinrich Klotz, Karlsruhe is a progressive university that focuses on philosophy, design, media, art, and architecture. Sloterdijk's work has only come to the attention of the English-speaking world relatively recently, in some part due to the advocacy of Bruno Latour, doyen of Science and Technology Studies. In his keynote address at the Networks of Design meeting of the Design History Society in Cornwall, Latour (2008) suggested, in typically provocative fashion, that it ought to have been Sloterdijk in his place. Since then, Latour $(2009,2010)$ has continued to advocate for Sloterdijk's work in various contexts, claiming to have been "born a Sloterdijkian” (p. 139), and suggesting that Sloterdijk's foam metaphor possesses many advantages over the popular network metaphor central to the actor-network theory.

This obscurity is not matched in Germany, where Sloterdijk is arguably the most well-known contemporary philosophical figure. In 2002, he began cohosting the popular German television program In the Glasshouse: The Philosophical Quartet, and was for some time embroiled in a widely publicized media stoush with Jürgen Habermas, long-time leader of the philosophical orthodoxy in the country who publicly accused Sloterdijk of resurrecting the kind of thinking associated with Third Reich politics — an accusation that Sloterdijk (2011a) compellingly analyzes and evaluates as lacking nuance over a series of extended interviews.

Sloterdijk (2011a) is arguably unique among contemporary philosophers due to the emphasis he places on space as a "key anthropological category" (p. 9). In Sloterdijk's wide-ranging analysis of human civilization, he proposes a theory of human evolution through a series of interlinked yet distinct developments in the form of buildings, and the associated biological, psychological, cultural, emotional, and systemic conditions with which they are accompanied. This article presents a curation and contextualization of a series of key examples from Sloterdijk's oeuvre that are particularly relevant to the study of interior spaces, a consideration that he suggests is essential to any adequate understanding of humans. After introducing and explaining some of the distinctive elements of Sloterdjik's philosophy, a brief account of his broader history as a thinker is given, before focusing on the third and final volume in his epic Spheres trilogy, Foams, in which he proposes that technological and cultural developments in the twentieth century can be suggestively interpreted using the metaphor of foam. In Sloterdijk's work, foam is the metaphorical expression of a generalized notion of dwelling and society that accounts for the way developments in architecture and telecommunications have serviced and been served by an ideal of co-isolated living. This aspect of Sloterdijk's work, and his theory of spatial immunity, which informs his thinking about space more broadly, is 
particularly germane for any program of research that attempts to interpret practices of human dwelling and sociality with a transdisciplinary orientation. It does this by demonstrating the ways in which an understanding of the metaphorical basis of language and becoming human can be used to create concepts that facilitate the successful integration of forms of knowledge from the sciences, humanities, design, and experiential ways of knowing.

This article is written according to a principle that puts sustained, in-depth attention to a particular text and author over ambitions of survey or critique in relation to other arguments. The intent is not to judge if Sloterdijk's various propositions bear out the claims they make through reference to evidence or application to further examples. Rather, the approach taken is informed by an intent to highlight the unique conceptual tools and modes of thinking employed by a thinker with deep relevance to the focus of this special issue: to integrate disparate perspectives on indoor life and ecologies. There is much opportunity for further work to be conducted using and evaluating Sloterdijk's often bold claims in relation to evidencebased sociological, scientific, and anthropological approaches.

\section{Techniques of Language, Immunity, Space, and Ecological Metaphysics}

An understanding of the rationale that informs Sloterdijk's stylistic decisions places readers in a better position to grasp the meaning expressed in the often peculiar language play evident in his philosophical analysis. Sloterdijk's style is characterized by a unique use of poetic techniques, in particular his abundant use of metaphor and hyperbole. This approach is informed by a stated commitment to exaggerating or recontextualizing the language games of other discourses. This stylistic decision is informed by an interpretation of "the human" that is mindful of the limitations of biological positivism and adequately accounts for the excessive dimension of humanity within the context of ecological history: "All the decisively human capabilities are exaggerations. Walking upright itself was already a hyperbole that could never be totally compensated for with biological advantages" (Sloterdijk, 2016, p. 31). These impressionistic but often captivating caricatures of evolutionary history are frequent in Sloterdijk's analysis. Like all caricatures, they are at once inexact and, if successful, expressive of a certain truth.

This stylistic inventiveness is further amplified by the numerous disciplinary voices that echo through his prose. He referred to the "trans-rational, trans-subjective, trans-experiential" (Sloterdijk, 2011a, p. 30) nature of the visionary thinking that informs well-rendered philosophical and poetic writing:

All my work moves in such trans-dimensions; it wanders between disciplines, languages, aspects. It could be understood as the literary materialization of an extended conception of the Enlightenment. (Sloterdijk, 2011a, p. 30) 
Understatement and notions of communicative competence are in this sense avoided in favor of exaggeration, irony (which he described as "an overreaction to the permanent annoyance of statements of facts" [Sloterdijk, 2011a, p. 31]), and metaphorical play-to this extent it is revealing that Sloterdijk (2011a, p. 204) toyed with presenting his Spheres project as a novel until the last minute.

The value of an interpretive or analytical approach grounded in hyperbole or exaggeration is advocated by a range of scholars for its potential to provide new epistemological and ontological insights (Ettenhuber, 2007; Ritter, 2012; Stanivukovic, 2007). Hyperbole, literally meaning to "throw beyond," is a mode of thought or a form of philosophical inquiry (Ritter, 2012). It is used variously in situations when language or thought must transcend epistemological and ontological boundaries to undermine or "throw beyond" literal meanings. In this sense, Sloterdijk's exaggerated and metaphoric portrayals of phenomena are intended not to capture empirical detail, but to enable us to think beyond the constraints that would usually inhibit our thinking.

In the context of this special issue, Sloterdijk's expanded use of the concept of "immunity" is a particularly instructive and relevant example of his metaphorical and hyperbolic play, which connects directly with the emphasis on space in his work. Sloterdijk's approach to thinking through concepts such as immunity demonstrates neither the indifference nor hostility shown by many humanist philosophers toward techno-scientific developments, nor any of the naive reverence for innovation and truth that informs hard-line advocates for salvation through such means. Instead, Sloterdijk practices philosophy as a way to express the broader cultural and historical implications of techno-scientific knowledge. Regarding the notion of immunity, he begins by emphasizing the distinctive paradox expressed through the idea, and the interpretative demands it puts on the various institutions that seek to shape what it means:

One must acknowledge that there are occult battles between pathogens and "antibodies" in the human organism whose results are responsible for the state of our health. Many biologists describe the somatic self as a besieged terrain defended by endogenous border troops with varying success. The users of this hawkish terminology are opposed by a fraction of biological doves who paint a less martial picture of immune processes; in this version, the self and the foreign are so interwoven at deep levels that overly primitive strategies of definition are more likely to have counterproductive effects. (Sloterdijk, 2016, p. 185)

Sloterdijk (2016) summarized the broad conceptual field associated with the immune concept, as defined by tendencies to assign more or less significance "to the presence of the foreign amidst the own" (p. 186). However, the discursive tensions between biological, political, legislative, and social dimensions that the idea of immunity brings into relation are accompanied by a further interpretive demand for a philosophy that attempts to think with the innovative ideas of modern science: 
It is not only through their complexity that the immune systems confuse their owners' longing for security; they cause even more perplexity through their immanent paradox, as their successes, if they become too thorough, are perverted to become their own kind of reasons for illness: the growing universe of auto-immune pathologies illustrates the dangerous tendency of the open to win itself to death in the battle against the other. (Sloterdijk, 2016, pp. 185-186)

In this sense, biochemical understandings of immunity are accompanied by degrees of complexity and paradox that enable the concept to function as a useful metaphor for interpreting a range of different systems and technological developments that play a defining role in modern societies. For example, Sloterdijk (2016) suggested that the development and dissemination of knowledge itself in techno-scientific cultures can have paradoxically adverse effects with regard to what he described as "the mental immune status of "enlightened society" (p. 186). By this he means to suggest that there is a perverse side to the view that more information will deliver greater degrees of immunity from risk, and that increases in knowledge-while delivering undeniable benefits for securing the ongoing safety of humans - can also trigger something comparable to a kind of autoimmune response at a psychocultural level. Smithson (1985) made compatible arguments with regard to utility-or in Sloterdijk's terms, the immune function-of ignorance in the conditions of uncertainty that are common to knowledge-abundant societies. In this sense, levels of mental stresses relating to risks or threats become impossible for individuals or collectives to adequately manage and begin to have adverse effects as the body politic begins to attack itself. The metaphor of autoimmune overreaction could also be aptly applied to contemporary concerns about "helicopter parenting," by which parental attempts to protect one's children from harm constitute an overreaction, which can lead to children becoming less resilient and lacking in the forms of mental and embodied knowledge required to develop necessary coping strategies for life.

Sloterdiijk follows this unpacking of the modern scientific notion of immunity with a broader historical account of the field of meanings, institutions, and practices associated with the word. While contemporary understandings of immunity are largely informed by scientific and medical understandings of the concept, Sloterdijk (2016, p. 500) points out that the older usage can be traced back to Roman law, when the term described a situation in which various entities, including cities, groups, and individuals, were granted exemption from obligations to the state or to a community - a meaning still retained in the current legal usage of the word. Sloterdijk's philosophical approach involves bringing together multiple meanings of this word across different fields of knowledge to think with language in a way that exploits its dynamic, rather than exclusively semantic possibilities - an approach that is common to poetry and literature. He allows the different but related definitions of immunity to ramify through his analysis such that an understanding of social and architectural contexts can be interpreted in a subtly changed way that reveals 
new light on notions of personal or shared immunity. This approach suggests a new way of thinking together across biology, architecture, ecology, anthropology, and sociology (Sloterdijk, 2016, p. 498).

Sloterdijk frames the historical, technological, and cultural developments associated with modernity as facilitating a distinctive kind of immune experience. He suggested that the religious and legal immune systems of the past are less pertinent to interpreting the modern condition than the architectural and technological systems that support routines of self-care and leisure:

The dwelling of the modern person is the body extension that provides a specific representation of their habitualized self-concern and backgrounded defensiveness. It renders explicit that living organisms do not exist without ensuring enclosure in themselves. Thus dwelling gains a share in the core process of modernization: it articulates the emergence_-or the becoming-explicit—of immune systems as well as the experimentation of self-referential units with larger associations (in which even the largest will still be far smaller than the "whole."). (Sloterdijk, 2016, p. 504)

The terms "emergence" or "becoming-explicit" are Sloterdijk's alternatives to the notions of national, technological, or scientific revolutions. In this sense, "becomingexplicit" or "explication" is the unfolding of forms of knowledge evident in religious and mythological practices, or otherwise vaguely known intuitions, through more precise and interwoven technological and systemic approaches. The promise of the architectural and technological realization of the immune function is "the basic right to ignore the outside world" (Sloterdijk, 2016, p. 501) so daily routines of self-care and self-expression (Sloterdijk emphasizes the interweaving of the two) can be performed and perfected.

While the archetypal architectural situation echoed in the above description is the solitary, narcissistic apartment dweller, it would be wrong to equate Sloterdijk's account of modern living as individualistically oriented in any simplistic sense. As he made clear in a feature for Harvard Design Magazine:

[a]ll being-in-the-world possesses the traits of coexistence. The question of being so hotly debated by philosophers can be asked here in terms of the co-existence of people and things in connective spaces. That implies a quadruple relationship: (1) Being means someone (2) being together with someone else (3) and with something else (4) in something. This formula describes the minimum complexity you need to construct in order to arrive at an appropriate concept of world. Architects are involved in this consideration, since for them being-in-the-world means dwelling in a building. A house is a three-dimensional answer to the question of how someone can be together with someone and something in something. In their own way, architects interpret this most enigmatic of all spatial pre-positions, namely the "in." (Sloterdijk, 2009, p. 6) 
The question of being in is among Sloterdijk's primary and most sustained philosophical focuses and explains his concern with examples of intimacy and interiority. This ranges from primitive interhuman and interspecies notions of intimacy such as bodily gestation, kissing, and biophilic relations with trees, to increasingly large-scale and complex modifications of interiority, such as airconditioning, gas warfare, popular music, and various paradigm-setting architectural examples, including the stadium and the modern apartment. Sloterdijk's metaphor of foam describes the architectural and social situation in which humans are at once enclosed within spatial extensions of themselves and in mediated relationships with larger, often weakly connected associations or collectives. This is a significantly different situation to the simple intimate relations such as those between mother and child, or smaller collectives - the focus of Sloterdijk's (2011b) first Spheres volume, Bubbles - which, nonetheless, still endure as crucial enabling layers within the more complex and transformed interiors and systems peculiar to the modern period.

Among the key antecedents for Sloterdijk's philosophy, and what makes his work such a good fit for the focus and ethos of the present journal, is the making explicit of the notion of the environment as a key focus in the biological and social sciences. He makes several references to, and his thinking is clearly influenced by, the work of the Estonian biologist Jakob von Uexküll (1992), who, writing in the first half of the twentieth century, used the metaphor of a soap bubble to express his concept of the microworld, or Umwelt. According to Sloterdijk (2016), Uexküll's theory and the broader notion of living creatures each inhabiting a specific ecology had a decisive effect on the way space and social life are conceived and demands a renewed approach to metaphysics:

When Jakob von Uexküll formulated the thesis that it had been a mistake to view the human world as a shared stage for all living creates, he was not only drawing the lifescientific from the deflation of the world soul-idea; he was also taking the step from monological metaphysics, which interprets the world as mono context and projects it onto a single eye, to a pluralistic ontology that estimates as many worlds as there are eye types and other sensors to see and feel them, without resorting to the hypostasis of an eye of all eyes (or a sensor of all sensors). (p. 230)

Uexküll's interpretation of the world as "countless millions of narrowly bounded bubbles that overlap and intersect everywhere" (cited in Sloterdijk, 2016, p. 230) is taken up into Sloterdijk's thinking as the metaphor of foam and extended to the point of rupture in his various conceptual and rhetorical acrobatics. Unlike the different religious and metaphysical conceptions of a unifying spiritual or perceptual forcewhether in the form of the gods in monotheistic religions, ancient conceptions of heavenly spheres, or nostalgic reiterations of these ideas in naive forms of holismSloterdijk's ecologically informed use of the foam metaphor emphasizes a complex, contingent, and irregular field of relations produced by diverse gatherings of beings. 
Sloterdijk's further contribution to the program set out by Uexküll is to characterize human spheres in a manner that is adapted to their specific properties. While he is clearly sympathetic to a decentered notion of ecological agency, Sloterdijk (2016) also argued that the human species possesses attributes that are not captured in Uexküll's biological conception of space, relationality, and perception:

The human households described here as cells in the social foam make use-beyond merely defensive provisions — of manifold expansion mechanisms extending from the setting-up of a living container, via the establishment of a personalised traffic system, to the creation of a customized world picture poem. Such observations provide a concept of immunity with aggressive qualities: starting from the biochemical layer of meaning, it moves up to an anthropological interpretation of the human modus vivendi as self-defence through creativity. (p. 232)

The notion of immunity as defensive force might be adequate for an understanding of biologically interpreted living things. However, in Sloterdijk's view, this lacks the scope to account for the exemplarity of humans with regard to creativity, in particular the technologically realized expressions of creativity that in modernity go by the modern name of "design."

Sloterdijk (2016) argued that attentiveness to creative excesses and multiple spatial environments of modern humanity sets his foam theory apart from other conceptions of the social:

The familiar suggestions for solutions offered by such concepts as division of labour (Smith, Durkheim), capital context (Marx), imitations and somnambulism (Tarde), interdependency (Simmel), sacrifice (Girard, Heinrich) or progressive differentiation and communication (Luhmann) all suffer from the same deficit: they do not adequately address the spatial qualities of social cells or the immune system character of primary spaces. (p. 235)

Sloterdijk is clearly influenced by all the thinkers listed in this critique, and makes regular and highly nuanced use of them in his work. For example, his notion of spatial immunity, or what he described as "the exemption from service to society" (Sloterdijk, 2016, p. 275), whether serviced by architecture or media, captures and emphasizes the latent indication in thinkers such as Simmel, Tarde, and Luhmann in particular, that "'societies' are composed of beings that must simultaneously stand inside and outside of their association" (p. 278). However, he nonetheless maintains the argument that their various conceptions of society proposed by the thinkers listed lack a rich enough metaphorical grasp of the spatial diversities, excesses, and commitments of humans and their technological extensions.

Sloterdijk's unique attentiveness to finding the right image to describe this highly nuanced conception of the psychosocial spaces inhabited by humans is recognized by Bruno Latour (2010)—arguably the contemporary thinker who, in his 
popularization of the network metaphor in actor-network theory, has done the most to advance a conception of the social that is most compatible with Sloterdijk's notion of foam:

As you may know, one of the criticisms often made about networks (particularly by Peter Sloterdijk) is that they are extremely poor metaphors since they remain entirely made of nodes and edges to which is often added some conveniently drawn potato-like circles ... To say that something is a network is about as appealing as to say that someone will, from now on, eat only peas and green beans, or that you are condemned to reside in airport corridors: great for traveling, commuting, and connecting, but not to live. Visually there is something deeply wrong in the way we represent networks since we are never able to use them to draw enclosed and habitable spaces and envelopes. (p. 5)

In contrast to the spatially impoverished notion of networks connecting in simple geometric space, Sloterdijk's psychoanalytically, poetically, and architecturally informed interpretation of human psychosocial space aims to give an account of the complex interweaving of physical and psychic space. In this sense, Sloterdijk's approach to philosophy is particularly compatible with the often unanswered promise of the discipline of design, which conceives humans as beings motivated by aesthetic desires that perpetually ramify in their level of nuance. The importance of the personalization of interiors as spaces that reflect multiple creative, protective, and connective urges is evident throughout his works. The next section will focus on a segment of Foams that gives sustained attention to the routines of apartment living as a platform for more abstract philosophical and poetic analysis.

\section{Immunity Practices and Apartment Life}

Sloterdijk (2016, p. 529) regarded the creation of the solitary apartment dweller as one of the key sociopsychological phenomena of the twentieth century. He employs a range of rhetorical and conceptual resources to animate a vision of this lifestyle as practiced by a relatively wealthy subject living in an advanced industrial democracy. The value of this approach comes from the simultaneous gathering of theories about contemporary media, quasi-physiological analysis of metabolic and sensory activity, and phenomenological-type descriptions of how this might be experienced by a hypothetical subject. Sloterdijk (2016) described the apartment as "at once stage and cave" where a "self-care cycle" is performed, which might include "a morning grooming session consisting of emptyings, washings, acts of cosmetic self-attention and clothings" (p. 650). The "universe of differentiations that are assigned great intrinsic value in the consciousness of users" are crucial in this stage of the practices of getting ready for daily life performances: "here combination becomes the duty of design, while selection becomes a self project" (Sloterdijk, 2016, p. 650). Next, the analysis moves to breakfast, which is also an occasion for the development of "self-care from a nutrition-critical perspective" (Sloterdijk, 2016, p. 551). According 
to Sloterdijk (2016), these "elementary gastrospheric standards" are, along with sanitary standards, the defining "concept of comfort in a modern housing unit" (p. 552).

Sloterdijk (2016) then turns his attention to the role of media in the unfolding of morning routines, which he describes with the characteristically enigmatic phrase the "anti-silentium," indicating the entry of sound into the "nocturnal soundfast":

This anti-silentium shows how the solitary apartment dweller takes their daily resocialization and attainment of worldliness into their own hands by having a say, through the choice of media, in the content and dosage of the reality influx.

(Sloterdijk, 2016, p. 552)

He is keen to point out that while in the past this outcome was achieved through reading, now it is more likely to be practiced through immersion in sound or (increasingly) audiovisuals, which, once released into broader public spaces, can be compared to "cells in sonorous foams; with reference to the countless competing listening collectives" (Sloterdijk, 2016, p. 554). The combined function of different media in the apartment space, whether paper, radio or television, allows for remote "world content" to enter into the space of the cell while it still "performs its defensive functions as an insulator, an immune system and a supplier of comfort and distance" (Sloterdijk, 2016, p. 555).

The three final focal points of Sloterdijk's account of apartment life include the role of the telephone, the elaboration of self-serving sex practices, and the maintenance of knowledge levels. Each of these points has implications for how apartments function as immune structures, and the psychological, cultural, and biophysical states that develop within indoor spaces. Sloterdijk (2016) regarded the key effect of the telephone as the introduction of a "two-way media" that enjoys the "double ontological privilege" of connecting the apartment dweller with the "domain of the real" and puts them into a "state of simultaneity" (p. 555) with the caller. This function is continued in contemporary Internet technology, which Sloterdijk (2016) suggested is "merely the continuation of the telephone by visual means" (p. 556). Telephonic technology is "an ambivalent innovation" with regard to maintaining the immune function of the apartment space: "it directs a canal for dangerous infections from the outside into the dwelling-cell, while conversely expanding the inhabitants radius - in the sense of larger alliances and opportunities for action-in an explosive fashion" (Sloterdijk, 2016, p. 556). This has significant consequences that are distinct from religious practices, which Sloterdijk compellingly characterizes as a kind of telecommunications technology, and print-based cultures. He argued that "modern telephone supported apartment lifestyle" represents a significant shift from the premodern era, in which "the most interesting messages came from a strong sender known as 'God'," to a phase in which such messages are to some 
extent trivialized, as individuals attempt to maintain a requisite level of interest in themselves, or that, failing, "focus on the lives of the stars" (Sloterdijk, 2016, p. 558).

The following section on sexuality adds a further notch to Sloterdijk's account of apartment lifestyle and the broader cultural trends through which it is informed. This is a world where sexual activity is now to a large extent released from its biological and social obligations as a force in the creation of offspring, and becomes a means by which individuals explore and experience erotic possibilities. Sloterdijk (2016) suggested that while biochemical contraceptives had a significant and "over-discussed" role in this change, it is also "inseparably connected to the gain in discretion through apartment culture, or at least to the securities of one's own room" (p. 559). Sloterdijk (2016, p. 560) cites the American feminist and masturbation activist Betty Dodson, who, in awarding herself a $\mathrm{PhD}$ in masturbation, offers an unimprovable characterization of the release of individuals into spaces and time to conduct research into their own erotic desires. However, such trends are not unidirectional, and Sloterdijk (2016) lent further nuance to his claims by alluding to recent literature on singles and by citing Dodson again, who admitted that she "intermittently resorted to penises" to avoid the onset of weariness associated with "auto-monogamy" (p. 561). Nonetheless, Sloterdijk (2016) suggested that studies have "shown beyond doubt" that such needs are not enough for singles to "accept the disturbance of their cellar peace through a permanent partner" (p. 561).

Lastly, Sloterdijk describes the role of modern telecommunications technology and its place in apartment lifestyle as supplying isolated individuals with the means to ensure adequate levels of knowledge are maintained. In light of the relatively small gains individuals make in self-education in comparison with the rate by which levels of knowledge increase at a systemic level across society, Sloterdijk (2016) preferred to call this "enlightened ignorance management" (p. 562). Knowledge in such contexts functions by affording individuals "the license to choose and have say" or in a manner comparable to "fashion items and markets," such that "people carry isolated particles of knowledge the same way they wear sunglasses, expensive watches or baseball caps" (Sloterdijk, 2016, p. 562).

Sloterdijk's hyperbolic characterization of a particular kind of modern interior life offers a thought-provoking and wide-ranging account of humans as beings shaped by complex cultural, environmental, and technological forces. The presence of exaggeration in the absence of any uniform, clearly identifiable, critical, or salutary perspective makes the reader more keenly aware of the not always enlightening role of totalizing or minutely detailed explanatory theories of social life. In this regard, Sloterdijk's approach can offer unique insights when compared to caricatured critiques of what is often given the misleadingly anodyne name "consumer culture," 
particularly those in the influential traditions of the Frankfurt School and Thorstein Veblen (see Denniss, 2017; Horowitz, 1985), and more broadly across sociology, cultural studies, economics, and consumer studies.

Studies of consumer culture have undoubtedly become more nuanced and inclined to detailed and situated ethnographic accounts of how and why people "consume" resources in different ways, particularly those investigating the "inconspicuous consumption" of resources that accompanies everyday activities, unrelated to symbol or status (Christensen, 2015; Eckhardt et al., 2015; Shove \& Warde, 2002). However, Sloterdijk's use of exaggeration and metaphor offer additional tools for critique that literal accounts of the minutia of daily life cannot. As noted in the above section "Techniques of Language," exaggeration and metaphor can serve to extend literal meanings to new fields of thought. Ritter (2012) further articulated the value of such techniques to multiple scholarly pursuits in his statement that exaggeration and hyperbole are:

a figure of thought that can highlight the limits of figuration and representation (Bloom, 2003), operate as a vehicle for the sublime (Marvick, 1986), destabilize norms and conventions, and encourage active reflection on "the different ways in which meaning is constructed and communicated" (Ettenhuber, 2007, 210). (p. 410)

Hyperbolic accounts can complement the rigorous and detailed observations of reality by offering a way of playing with the meanings offered at "the extreme boundaries of thought" (Stanivukovic, 2007, p. 20), thus, enabling an interruption of the language and logic of the existing argument, which can shift "one level of meaning to another, re-invented meaning" (p. 20). An argument for the value of this approach can be made through an analogy to similar arguments created for the use of different media in the sociological studios of scientific practices. For example, Peter Galison (2014) made a compelling case that the medium of film can reveal unique things about scientific practice, specifically the visceral, atmospheric, and particular dimensions of the everyday that are not captured using the standard conventions of academic publication. Likewise, through different techniques of rhetoric rather than media, Sloterdijk evokes an image or story of humans that is not reducible to the genres of novelistic, poetic, historiographic, and philosophical writing from which it borrows. The work is too philosophically conceptual in its explorations of technology for novelistic writing, far more attentive to the description of everyday life than is permissible in philosophical analysis, too thesis driven for poetry, and too impressionistic for history. Yet, in this rag-and-bone approach, Sloterdijk evokes a uniquely post-human account of humans, which demonstrates the subtle dynamics that animate the relationship between routine and dwelling, media and psychology, and the historical and futuristic dimensions of technology. The concluding section of this article will discuss in a more explicit fashion how Sloterdijk's philosophical 
exploration of the "in" extends to an analysis of how broader conceptions of climate, atmosphere, and environment have become increasingly important at a subjective level during the modernization processes of the twentieth century.

\section{Air Design}

The difference between Sloterdijk's technologically informed approach to philosophical analysis and the phenomenological approaches that have been so influential in descriptions of human subjectivity is marked out in a particularly pronounced fashion when approaching the topic of air. Unlike phenomenological advocates of air, such as Luce Irigaray (1999), Sloterdijk (2016, p. 196) stressed that the air cannot be adequately understood without reference to the technical and environmental changes inflicted on the atmosphere over the course of the last 200 years. Phenomenological accounts, particularly those that call for greater attention to be paid to the air (such as Irigaray's), ignore all the crucial ways in which the air has already been made explicit, and been explicitly utilized, for various aerotechnic practices. Some of these include colonizing the air with gas in warfare to make the atmosphere uninhabitable to opponents, and researching the possibilities for larger scale atmospheric terrorism.

By contrast, using his characteristic blend of poetic and conceptual thinking, Sloterdijk explores the philosophical implications of significant air-related events over the twentieth century, including "atmoterrorism" practices evident in gas and aerial warfare; the interaction between the weather, science, the media, and subjectivity expressed in the convention of the weather report; and the hugely influential, continuously evolving "aerotechnic" practices that service the increasing demands for comfort, which are characteristic of indoor life in the modern period. These and other grouped-together technological and conceptual developments in air design are, according to Sloterdijk (2016), compelling expressions of the view for which anyone attempting to understand the originality of the twentieth century must account: "the practice of terrorism, the concept of product design and the environmental idea” (p. 85).

Gas warfare is a forceful example of the explication or highlighting of the atmospheric (a word it is worth remembering literally means "vapor ball") conditions human subjects and collectives must persist. Sloterdijk (2016) described the first "largescale use of chlorine gas as a warfare agent" on April 22, 1915 (p. 86) as a decisive event in the development of both terrorism and environmental thinking:

This is, in fact, the point at which traditional war becomes terrorism, assuming the latter is based on a rejection of the old crossing of blades between equal opponents. Current terror operates beyond the naive exchange of armed strikes between regular troops. Its concern is to replace classical battle forms with attacks on the enemy's environmental preconditions for life. (pp. 91-92) 
These distinctive martial conditions are supported by a staggering set of statistics cited by Sloterdijk (2016):

When one learns from military history that between February and June 1916, the responsible field depot supplied almost five and a half million gas masks and 4,300 breathing apparatuses (mostly taken from the mining industry) with two million litres of oxygen to the German troops at Verdun alone, it becomes evident in numbers how far "ecologised" war, a war brought into the atmospheric environment, had become a battle for the respiratory potentials of hostile parties. Combat now incorporated the biological weak points of the conflict partners. (p. 95)

The first environmental attack of gas warfare provoked a rapid and large-scale design response to augment the human body with the technological means to persist in an atmosphere hostile to life. In this sense, gas warfare "introduced the operative criteria of the twentieth century-terrorism, design-consciousness, and an environmental approach-in close union" (Sloterdijk, 2016, p. 96).

Sloterdijk (2016) traced developments in atmoterrorism from these initial uses of gas warfare in World War I, through the industrial-scale extermination camps used in World War II, to gas chambers used sporadically in United States (US) for executions, and the "explication of radioactive matter through nuclear power," which resulted in a "reordering of 'environmental' awareness towards the invisible milieu of waves and rays" (p. 130). He concluded this focus with reference to a paper presented to the US Department of Defense on June 17, 1996, which bears the chilling title, Weather as a Force Multiplier: Owning the Weather in 2025 (House et al., 1996), and the following, equally chilling, strategic ambition:

A high-risk, high-reward endeavour, weather modification offers a dilemma not unlike the splitting of the atom. While some segments of society will always be reluctant to examine controversial issues such as weather modification, the tremendous military capability that could result from this field are ignored at their own peril. (cited in Sloterdijk, 2016, p. 139)

Exactly 110 years on from the first large-scale uses of atmoterrorism in World War I, these intentions to develop weather-modification technology and the rationale that supports them signal the potential of a new era in advanced military combat. Details on the contemporary progress of such research are notoriously difficult to access. However, in light of the increasing commonality of nonmilitary climate-design technologies, such as cloud seeding and the evident strategic advantages of large-scale climatic attacks, it seems entirely plausible that this is an area the military will continue to explore. Further, with spending on military research and development in the US (or any other world power) unlikely to dip in the near future, the nonmilitary spinoffs of these large-scale climate manipulations will have significant and unforeseen consequences for industries around the world, from agriculture, to tourism, and the ever-expanding indoor biomes that populate these regions. 
Sloterdijk (2016) proposed that the large-scale environmentally destructive potentials of modern military technology is one expression of "a progressive subjectification of the weather" (p. 161). This subjectification is also occurring at meso and microscales, for which he contended humans have become "weather clients" (p. 161) through the performance of weather reporting, associated weather travel or tourism (Sloterdijk mentions vacations for Northerners in the winter months to Morocco and Mallorca), and air-conditioning developments in shopping malls and homes designed to sustain thermal comfort for the ongoing presence of human users. Both these macroscale militaristic and mesoscale comfort-inspired developments represent a subjectification of the weather through both the rhetorical and performative techniques used in the reports, and the technological adaptations of climate to the body evidenced in air-conditioning.

Sloterdijk's (2016) amusing characterization of the modern weather report as "a performance given by a nature for society" by which "meteorologists gather people to form an audience of connoisseurs under a shared sky" (p. 160) provokes a renewed consideration of this perhaps taken-for-granted, everyday convention. Like other significant natural events such as birth and death, the weather is no longer the domain of God or nature, but a context for the "nuancing activities" (Sloterdijk, 2016, p. 787) of modern humans, whether the calculations of meteorologists or the intersubjective planning programs of kinetic elites who escape their colder northern locales to warmer countries in the winter months. At a more local level, the weather report and its digital equivalent, the weather app, functions as a permanently accessible discussion-generating tool through which users "compare their personal perception with the briefing and form an opinion about ongoing events" (Sloterdijk, 2016, p. 159).

The notion of air design, or what Sloterdijk (2016) also called "atmotechnics" (p. 165), is realized in micro and meso levels in the air-conditioning technology and associated practices that increasingly shape public and private spaces over the course of the twenty-first century. Sloterdijk suggested that various air-conditioning and climate-control technologies have both enabled and testify to the "addiction to dwelling" (Sloterdijk, 2016, pp. 169-170), expressed as a preference for conducing all manner of activities indoors. As with his discussion of the "greenhouse effect" in the second Spheres volume Globes, Sloterdijk (2014) reinvigorates the interpretative potential of the otherwise inconspicuous notion of air-conditioning by grounding it in significant historical examples and extending the metaphor to culture more broadly. Following the insights of Hermann Broch and Elias Canetti, he suggested that the "mood modification" techniques used in air-conditioning practices of commercial shopping centers, offices, and private residences are metaphorically interpretive of the personal media ecologies and mass communication technologies that are among the defining features of life in the twentieth century and beyond: "Broch had realized that after the intentional destructions of the atmosphere in 
chemical warfare, social synthesis itself took on the character of gas warfare in some respects, as if atmoterrorism had turned inwards" (Sloterdijk, 2016, p. 174). Similar ideas have been suggested by the French philosopher of science Michel Serres, who suggested that the new metaphysics of the information ages is "more liquid than solid, more air like than liquid, more informational than material" (Serres \& Latour, 1995, p. 121), and demonstrated a comparative appeal, with efforts by Stokols (2018), to expand the study of social, or human, ecology into the digital realm.

\section{Conclusion}

This article has made the argument that Sloterdijk's philosophy is a distinctively thought-provoking resource for scholars whose work focuses on investigating indoor ecologies from different perspectives. It proposes that Sloterdijk's work provides a basis for integrating perspectives from natural and social scientific disciplines, which is particularly attentive to the spatial, physical, and experiential manifestation of knowledge as architecture and design. Sloterdijk's commitment to practicing philosophy according to multiple logics and stylistic devices allows him to explore the boundaries of human thinking by approaching language as something that has a dynamic, rather than static or simply definitional, relationship with meaning. In this regard, the hyperbolic and metaphorical techniques Sloterdijk employs allow him to evolve diverse yet cohesive understandings of concepts such as immunity, the cell, foam, and the atmosphere, which are often dulled through exclusive usage in their disciplinary sites. The elaboration and curation of his ideas evidenced in this article are intended to prompt scholars from different disciplines to further explore his work, and use it as a reference point in research into indoor ecologies that requires framing in relation to broader sociotechnical trends and the futures to which they may give rise.

\section{References}

Bloom, H. (2003). A map of misreading. New York, NY: Oxford University Press.

Christensen, C. (2015). Two kinds of economy, two kinds of self-toward more manageable, hence more sustainable and just supply chains. Human Ecology Review, 21(2), 3-21. doi.org/10.22459/HER.21.02.2015.01

Denniss, R. (2017). Curing affluenza: How to buy less stuff and save the world. Melbourne, Vic.: Black Inc.

Eckhardt, G. M., Belk, R. W., \& Wilson, J. A. (2015). The rise of inconspicuous consumption. Journal of Marketing Management, 31(7-8), 807-826. doi.org/10.1080/ 0267257X.2014.989890 
Ettenhuber, K. (2007). Hyperbole: Exceeding similitude. In S. Adamson, G. Alexander, \& K. Ettenhuber (Eds.), Renaissance figures of speech (pp. 197-216). Cambridge, UK: Cambridge University Press.

Galison, P. (2014). Visual STS. In A. Carusi, A. S. Hoel, T. Webmoor, \& S. Woolgar (Eds.), Visualization in the age of computerization (pp. 197-225). New York, NY: Routledge.

Horowitz, D. (1985). The morality of spending: Attitudes toward the consumer society in America, 1875-1940. Baltimore, MD: Johns Hopkins University Press.

House, T. J., Near Jr, J. B., Shields, W. B., Celentano, R. J., \& Husband, D. M. (1996). Weather as a force multiplier: Owning the weather in 2025. Montgomery, AL: Air War College, Maxwell Air Force Base.

Irigaray, L. (1999). The forgetting of air in Martin Heidegger (M. B. Mader, Trans.). London, UK: Athlone Press.

Latour, B. (2008, September). A cautious Prometheus? A few steps toward a philosophy of design (with special attention to Peter Sloterdijk). In Proceedings of the 2008 Annual International Conference of the Design History Society (pp. 1-10). Retrieved from www.bruno-latour.fr/sites/default/files/112-DESIGN-CORNWALL-GB.pdf

Latour, B. (2009). Spheres and networks: Two ways to interpret globalization. Harvard Design Magazine, 30, 138-144. Retrieved from www.bruno-latour.fr/node/145

Latour, B. (2010, February). Networks, societies, spheres: Reflections of an actor-network theorist. In International Seminar on Network Theory: Network Multidimensionality in the Digital Age (pp. 1-18). Los Angeles, CA: Annenberg School for Communication and Journalism.

Marvick, L. W. (1986). Mallarme and the sublime. Albany, NY: State University of New York Press.

Ritter, J. R. (2012). Recovering hyperbole: Rethinking the limits of rhetoric for an age of excess. Philosophy \& Rhetoric, 45(4), 406-428. doi.org/10.1353/par.2012.0012

Serres, M., \& Latour, B. (1995). Conversations on science, culture, and time (R. Lapidus, Trans.). Ann Arbor, MI: University of Michigan Press.

Shove, E., \& Warde, A. (2002). Inconspicuous consumption: the sociology of consumption, lifestyles and the environment. In R. Dunlap, F. Buttel, P. Dickens, \& A. Gijswijt (Eds.), Sociological theory and the environment: Classical foundations, contemporary insights (pp. 230-251). Lanham MA: Rowman \& Littlefield.

Sloterdijk, P. (2009). Spheres theory: Talking to myself about the poetics of space. Harvard Design Magazine, 30, 1-8. Retrieved from www.harvarddesignmagazine.org/issues/30/ talking-to-myself-about-the-poetics-of-space

Sloterdijk, P. (2011a). Neither the sun nor death (S. Corcoran, Trans.). Los Angeles, CA: Semiotext(e). 
Sloterdijk, P. (2011b). Spheres: Microspherology. Vol. I: Bubbles (W. Hoban, Trans.). Los Angeles, CA: Semiotext(e).

Sloterdijk, P. (2013). You must change your life: On anthropotechnics (W. Hoban, Trans.). Cambridge, UK: Polity Press.

Sloterdijk, P. (2014). Spheres: Macrospherology. Vol. II: Globes (W. Hoban, Trans.). Los Angeles, CA: Semiotext(e).

Sloterdijk, P. (2016). Spheres: Pluralspherology. Vol. III: Foams (W. Hoban, Trans.). Los Angeles, CA: Semiotext(e).

Smithson, M. (1985). Toward a social theory of ignorance. Journal for the Theory of Social Behaviour, 15(2), 151-172. doi.org/10.1111/j.1468-5914.1985.tb00049.x

Stanivukovic, G. V. (2007). "Mounting above the truthe": On hyperbole in English Renaissance literature. Forum for Modern Language Studies, 43(1), 9-33. doi.org/10.1093/ fmls/cql112

Stokols, D. (2018). Social ecology in a digital age: Solving complex problems in a globalized world. London, UK: Academic Press/Elsevier.

von Uexküll, J. (1992). A stroll through the worlds of animals and men: A picture book of invisible worlds. Semiotica, 89(4), 319-391. doi.org/10.1515/semi.1992.89.4.319 
This text is taken from Human Ecology Review, Volume 24, Number 2, 2018, published by ANU Press, The Australian National University, Canberra, Australia.

doi.org/10.22459/HER.24.02.2018.08 